\title{
RANCANG BANGUN DAN IMPLEMENTASI MEDIA PEMBELAJARAN MATEMATIKA BERBASIS LECTORA INSPIRE DENGAN PENDEKATAN SAINTIFIK
}

\author{
I Putu Pasek Suryawan \\ Program Studi Pendidikan Matematika, Fakultas MIPA, Universitas Pendidikan Ganesha \\ Email: pasek.suryawan@yahoo.co.id
}

\begin{abstract}
ABSTRAK
Gagasan mengintegrasikan Lectora inspire dalam penyajian media pembelajaran dengan Pendekatan Saintifik memberikan nuansa baru dalam pembelajaran matematika pada penerapan Kurikulum 2013. Lectora Inspire merupakan software bantu yang telah terintegrasi dengan berbagai tools yang dibutuhkan untuk membuat konten multimedia yang bersifat interaktif dengan dilengkapi tiga fitur utama, yaitu: (1) camtasia for lectora, (2) snagit for lectora, dan(3) flypaper for lectora, sehinggacocok dalam mendukung pembuatan media pembelajaran berbasis TIK dengan pendekatan saintifik.Sebagai upaya mendukung inovasi tersebut dilakukan penelitian pengembangan untuk membuat media pembelajaran matematika berbasis lectora inspire dengan pendekatan saintifik untuk kelas VIII pada materi Sistem Koordinat.Pengembangan media pembelajaran dalam penelitian ini mengikuti prosedur pengembangan produk Model ADDIE (analysis, design, develop, implementation, dan evaluation). Teknik analisis data yang digunakan adalah teknik analisis data kualitatif dan deskriptif kuantitatif. Melalui tahap analysis dan design telah didapatkan rancang bangun dari media pembelajaran berbasis lectora inspire dengan pendekatan saintifik pada materi Sistem Koordinat, dan selanjutnya rancang bangun yang disusun telah diimplementasikan menjadi suatu media pembelajaran yang telah divalidasi oleh ahli pada tahap develop. Hasil validasi ahli menyatakan bahwa media pembelajaran yang dikembangkan tergolong pada kategori sangat valid dengan sedikit perbaikan, dan siap untuk diujicobakan terbatas pada tahap implementation.
\end{abstract}

Kata kunci: media pembelajaran sistem koordinat, lectorainspire, pendekatan saintifik.

\begin{abstract}
The idea of integrating Lectora Inspire in the presentation of learning medium with a scientific approach provided a new nuance in mathematics learning in the application of the 2013 Curriculum.Lectora Inspire is an aid software that has been integrated with various tools needed to create multimedia content that is interactive with three main features, namely: 1) camtasia for lectora, (2) snagit for lectora, and (3) flypaper for lectora, so that it is suitable in supporting the making of ICT-based learning medium with a scientific approach. To support this innovation a development research was conducted to make mathematics learning medium based on lectora inspire with a scientific approach to class VIII on Coordinate System material. The development of learning medium in this study follows the procedure for product development of the ADDIE Model (analysis, design, develop, implementation and evaluation). The data analysis technique used is the technique of data analysis of qualitative and quantitative descriptive. Through the analysis and design stages, the design of the lectora inspire based learning medium has been obtained with a scientific approach to the Coordinate System material, and then the compiled design has been implemented into a learning medium that has been validated by experts at the develop stage. The results of expert validation state that the learning medium developed are categorized as very valid with little improvement, and are ready to be tested limited to the implementation stage.
\end{abstract}

Keywords: coordinate system learning medium, lectora inspire, scientific approach. 


\section{PENDAHULUAN}

Pembelajaran merupakan suatu sistem yang bertujuan untuk membantu proses belajar siswa, yang berisi serangkaian peristiwa yang dirancang, disusun sedemikian rupa untuk mendukung dan mempengaruhi terjadinya proses belajar siswa yang bersifat internal (Parwati dkk, 2018). Tujuan pembelajaran lebih mudah tercapai apabila pembelajaran berlangsung secara efektif. Pembelajaran yang efektif ditandai dengan terjadinya pembelajaran dalam diri peserta didik, yaitu terjadi perubahan dari tidak tahu menjadi tahu, dari tidak mengerti menjadi mengerti, dan sebagainya. Namun kenyataanya, masih terdapat proses pembelajaran yang berjalan kurang efektif sehingga tujuan pembelajaran tidak tercapai sepenuhya.

Menurut Hamalik (2011: 57), pembelajaran merupakan suatu kombinasi yang tersusun meliputi unsur-unsur manusiawi, material, fasilitas, perlengkapan, dan prosedur yang saling mempengaruhi mencapai tujuan. Dengan adanya kemajuan teknologi, proses pembelajaran sekarang berlangsung dengan berbagai variasi pendekatan pembelajaran serta ditunjang dengan fasilitas pembelajaran yang canggih seperti LCD proyektor dan software-sofware pembelajaran. Selain itu, dampak lainnya yaitu siswa mudah mengakses informasi untuk mendapatkan sumber-sumber belajar yang menarik dan relevan.

Menurut Adipurnomo (2006: 6), sumber belajar dapat diartikan sebagai segala apa saja yang dapat digunakan dan dimanfaatkan dalam proses pembelajaran guna memudahkan pencapaian tujuan pembelajaran. Salah satu sumber belajar yang dapat digunakan adalah media pembelajaran. Menurut Arsyad (2011: 2), media adalah alat yang menyampaikan atau mengantarkan pesan-pesan pembelajaran. Selain itu, media pembelajaran dapat diartikan sebagai segala bentuk alat komunikasi yang bisa digunakan dalam penyampaian informasi dari sumber atau guru kepada siswa bertujuan agar dapat merangsang pikiran, minat, dan perhatian siswa untuk mengikuti pembelajaran (Supriyanto, 2016: 9).

Dalam pembuatan media pembelajaran perlu pemilihan, perencanaan, dan pertimbangan yang matang untuk menghasilkan media pembelajaran yang interaktif (Musfiqon, 2012). Penggunaan media pembelajaran interaktif ini memiliki beberapa nilai tambah yang perlu digunakan dalam pembelajaran. Media pembelajaran berbasis teknologi informasi dan komunikasi dirasa cocok pada jaman kemajuan teknologi yang pesat ini. Namun, masih banyak pendidik yang belum memanfaatkan media pembelajaran berbasis teknologi dalam proses pembelajaran. Hal itu disebabkan oleh terbatasnya media pembelajaran berbasis teknologi pada beberapa mata pelajaran di sekolah, salah satunya pada mata pelajaran matematika yang sering dianggap momok bagi siswa.

Berdasarkan hasil wawancara dengan tiga guru matematika SMP kelas VIII, diketahui bahwa pembelajaran matematika masih banyak terkendala dalam penyampaian materi, khususnya pada materi Sistem Koordinat. Pada sistem koordinat sebagian siswa sulit dalam menentukan posisi titik pada bidang Cartesius, dimana siswa sering terbalik dalam memosisikan nilai dari koordinat $x$ dan koordinat $y$ dari suatu titik. Siswa terkadang juga terbalik dalam menentukan 
sumbu- $x$ dan sumbu-y. Selain itu, siswa sulit untuk memvisualisasikan sistem koordinat khususnya koordinat Cartesius dikarenakan siswa tidak dapat berinteraksi secara langsung dengan gambar tersebut, yang mana siswa hanya mencermati gambar seperti pada buku ajar, slide, atau yang digambar oleh guru di papan tulis. Dengan tidak dapatnya berinteraksi secara langsung dengan visualisasi-visualisasi gambar tersebut, nantinya akan berpengaruh pada kualitas proses pembelajaran selanjutnya.

Untuk mengatasi permasalahan tersebut, sudah banyak usaha yang dilakukan untuk mengembangkan media pembelajaran berbasis teknologi informasi dalam pembelajaran matematika khususnya pada materi Sistem Koordinat. Misalnya penelitian dari Ave Graceota (2016) yang telah mengembangkan media pembelajaran matematika pada materi sistem koordinat di kelas VIII, penelitian Pery Zakaria (2014) yang berjudul pengembangan instructional video berbasis multimedia untuk materi sistem koordinat, dan penelitian Agung Kartika Putra (2014) yang telah mengembangkan media video pembelajaran dengan model ADDIE yang dinyatakan telah memenuhi kriteria valid, praktis, dan efektif sehingga layak untuk digunakan sebagai media pembelajaran di sekolah. Setelah dianalisis lebih lanjut, pada umumnya kegunanaan media pembelajaran yang telah dikembangkan sebelumnya hanya digunakan sebagai pelengkap pembelajaran sehingga masih perlu dikembangkan dan masih perlu ditambahkan beberapa aspek penting. Adapun aspek-aspek tersebut, yaitu: (1) media pembelajaran yang dapat berdiri sendiri, artinya siswa dapat menggunakan media pembelajaran tersebut tanpa harus dituntun oleh seorang guru; (2) media pembelajaran difasilitasi dengan eksplorasi, sehingga pengetahuan yang didapat siswa tidak terbatas; dan (3) disesuaikan dengan pendekatan kurikulum yang berlaku yaitu Kurukulum 2013, pembelajaran hendaknya memfasilitasi siswa untuk menemukan konsep sesuai pemahamanya sendiri (Wirapathi, 2018).

Mengatasi kekurangan-kekurangan dari media pembelajaran yang sudah ada agar sejalan dengan tujuan pembelajaran dari kurikulum 2013, yaitu dengan mengkondisikan pola pembelajaran yang berpusat pada siswa, dimana siswa harus aktif untuk mencari atau mengeksplorasi sendiri pengetahuan yang dibutuhkan oleh mereka (Daryanto, 2014). Oleh karena itu, dipandang perlu dilakukan pengembangan media pembelajaran yang disusun berdasarkan Pendekatan Saintifik. Pendekatan saintifik ini merupakan pendekatan yang diterapkan pada Kurikulum 2013, yang mana dengan diakomodasinya pendekatan saintifik pada media pembelajaran diharapkan siswa menjadi aktif dan mandiri dalam pembelajaran di kelas menggunakan media pembelajaran. Poin penting pada kurikulum 2013 ini adalah melaksanakan pembelajaran dengan pendekatan saintifik yang mampu menciptakan pembelajaran yang aktif (Sufairoh, 2016). Adapun pendekatan saintifik tersebut terdiri dari 5M, yaitu: (1) Mengamati, (2) Menanya, (3) Mengumpulkan Informasi, Mengasosiasi, dan (5) Mengomunikasikan. Namun tidak menutup kemungkinan juga bahwa media pembelajaran hanya digunakan sebagai pelengkap pembelajaran.

Pengembangan media pembelajaran dengan pendekatan saintifik 
ini dapat dibuat berdasarkan softwarebantu seperti Lectora Inspire. Lectora inspire merupakan sejenis authoring tools (alat penyusun multimedia) yang efektif dalam membuat media pembelajaran (Mas'ud, 2012). Lectora inspire telah terintegrasi dengan berbagai tools yang dibutuhkan untuk membuat konten multimedia yang bersifat interaktif dengan sangat mudah dan cepat karena dilengkapi dengan tiga fitur, diantaranya: (1) Camtasia for Lectora, (2) Snagit for Lectora, dan (3) Flypaper for Lectora.Camtasia for lectora, yaitu aplikasi yang mampu merekam aktivitas yang dilakukan pada layar kerja komputer, sehingga tercipta sebuah video aktivitas layar kerja komputer dan dapat digunakan juga untuk mengedit video serta animasi flash. Snagit for lectora, yaitu aplikasi yang mampu menciptakan potret layar kerja komputer dengan resolusi tinggi, untuk nantinya digunakan pada media pembelajaran. Flypaper for lectora, yaitu aplikasi yang mampu membuat media pembelajaran lebih kreatif dengan melibatkan dan menambahkan animasi flash dan efek special. Fitur-fitur tersebut sangat cocok dalam mendukung pembuatan media pembelajaran dengan menggunakan pendekatan saintifik seperti yang diharapkan pada penerapan Kurikulum 2013 (Wirapathi, 2018).

Berdasarkan uraian tersebut di atas, media pembelajaran yang mampu mendukung penerapan Kurikulum 2013 sampai saat ini masih dikatakan terbatas. Oleh karena itu, penulis mencoba mengembangkan media pembelajaran berbasis teknologi informasi dan komunikasi melalui penelitian pengembangan, dengan judul "Pengembangan Media Pembelajaran Sistem Koordinat Berbasis Lectora Inspire dengan Pendekatan Saintifik Untuk Siswa
SMP”. Adapun tujuan yang ingin dicapai dalam penelitian ini, yaitu: (1) membuat rancang bangun media pembelajaran sistem koordinat berbasis lectora inspire dengan pendekatan saintifik untuk siswa SMP; (2) mendeskripsikan hasil implementasi media pembelajaran sistem koordinat berbasis lectora inspire dengan pendekatan saintifik untuk siswa SMP; dan (3) mengetahui keterpakaian media pembelajaran sistem koordinat berbasis lectora inspire dengan pendekatan saintifik untuk siswa SMP. Media ini diharapkan dapat menambah sumber belajar yang efektif dan relevan dalam mata pelajaran matematika khususnya materi sistem koordinat, dan mendukung penerapan Kurikulum 2013.

\section{METODE PENELITIAN}

Jenis penelitian ini adalah penelitian pengembangan. Penelitian pengembangan dapat diartikan sebagai metode penelitian yang mempunyai tujuan untuk mencari, menemukan, memperbaiki, mengembangkan, menghasilkan produk, menguji produk, sampai dihasilkannya suatu produk yang sesuai dengan indikator yang telah ditetapkan (Yuberti, 2014). Model penelitian pengembangan yang digunakan adalah Model ADDIE, yang terdiri atas lima tahapan, yaitu (1) analyze (analisis), (2) design (perancangan), (3) development (pengembangan), (4) implementation (implementasi), dan (5) evaluation (evaluasi). Pada tulisan ini diuraikan hanya sampai pada menghasikan prototype berupa Media Pembelajaran Sistem Koordinat Berbasis Lectora Inspire dengan Pendekatan Saintifik yang sudah dievaluasi para ahli dan siap untuk diuji cobakan secara terbatas. Dengan demikian, pada tulisan ini hanya sampai pada tahap development (perancangan). Secara garis besar, tahapan kegiatan pengembangan dan luaran yang diharapkan pada penelitian ini disajikan seperti pada Tabel 1 berikut. 


\begin{tabular}{|c|c|c|}
\hline Tahapan & $\begin{array}{c}\text { Uraian } \\
\text { Kegiatan }\end{array}$ & $\begin{array}{l}\text { Luaran yang } \\
\text { Diharapkan }\end{array}$ \\
\hline $\begin{array}{l}\text { Analisis } \\
\text { (analyze) }\end{array}$ & $\begin{array}{l}\text { a. Menganalisis } \\
\text { kurikulum. } \\
\text { b. Menganalisis } \\
\text { materi. } \\
\\
\text { c. Menganalisis } \\
\text { media } \\
\text { pembelajaran. }\end{array}$ & $\begin{array}{l}\text { a. Diketahui } \\
\text { kurikulumyan } \\
\mathrm{g} \text { digunakan } \\
\text { pada kelas } \\
\text { VIII di SMP } \\
\text { Negeri } 3 \\
\text { Tembuku } \\
\text { Bangli } \\
\text { menggunakan } \\
\text { Kurikulum } \\
\text { 2013. } \\
\text { b. Teridentifikas } \\
\text { i } \\
\text { permasalahan } \\
\text { umum dalam } \\
\text { pembelajaran } \\
\text { matematika, } \\
\text { yaitu pada } \\
\text { materisistem } \\
\text { koordinat. } \\
\text { c. Media } \\
\text { pembelajaran } \\
\text { yang } \\
\text { digunakan } \\
\text { sebatas papan } \\
\text { tulis, spidol, } \\
\text { dan buku ajar. }\end{array}$ \\
\hline $\begin{array}{c}\text { Perancanga } \\
\mathrm{n}(\text { Design })\end{array}$ & $\begin{array}{l}\text { a. Menyusun } \\
\text { rancangan } \\
\text { media } \\
\text { pembelajaran } \\
\text { yang akan } \\
\text { dikembangkan } \\
\text { b. Menyusun } \\
\text { flowchart, } \\
\text { rancang } \\
\text { bangunmedia } \\
\text { pembelajarany } \\
\text { ang } \\
\text { dikembangkan } \\
\text { c. Menyusun } \\
\text { angket ahli } \\
\text { media, angket } \\
\text { ahli materi, } \\
\text { angket respon } \\
\text { siswa dan } \\
\text { guru yang } \\
\text { digunakan } \\
\text { untuk } \\
\text { mengukur } \\
\text { kevalidan dan } \\
\text { kepraktisan } \\
\text { media. }\end{array}$ & $\begin{array}{l}\text { a. Tersusunnya } \\
\text { rancangan } \\
\text { media } \\
\text { pembelajaran } \\
\text { yang akan } \\
\text { dikembangka } \\
\text { n. } \\
\text { b. Tersusunnyafl } \\
\text { owchart dan } \\
\text { rancang } \\
\text { bangun media } \\
\text { pembelajaran. } \\
\text { c. Tersusunnya } \\
\text { angket ahli } \\
\text { media, angket } \\
\text { ahli materi, } \\
\text { angket respon } \\
\text { siswa dan } \\
\text { guru. }\end{array}$ \\
\hline $\begin{array}{c}\text { Pengemban } \\
\text { gan } \\
\text { (Developm }\end{array}$ & $\begin{array}{l}\text { a. Mengimpleme } \\
\text { ntasikan } \\
\text { rancang }\end{array}$ & $\begin{array}{l}\text { a. Dihasilkannya } \\
\text { Prototype I } \\
\text { yang belum }\end{array}$ \\
\hline
\end{tabular}

\begin{tabular}{|c|c|c|}
\hline Tahapan & $\begin{array}{c}\text { Uraian } \\
\text { Kegiatan }\end{array}$ & $\begin{array}{c}\text { Luaran yang } \\
\text { Diharapkan }\end{array}$ \\
\hline ent) & $\begin{array}{l}\text { bangun media } \\
\text { pembelajaran } \\
\text { dengan } \\
\text { menggunakan } \\
\text { softwareaplika } \\
\text { si. } \\
\text { b. Melakukan } \\
\text { revisi terhadap } \\
\text { media } \\
\text { pembelajaran } \\
\text { berdasarkan } \\
\text { saran ahli } \\
\text { media dan } \\
\text { materi. }\end{array}$ & $\begin{array}{l}\text { divalidasi. } \\
\text { b. Dihasilkannya } \\
\text { Prototype I } \\
\text { yang sudah } \\
\text { direvisi sesuai } \\
\text { dengan } \\
\text { kriteria valid. }\end{array}$ \\
\hline $\begin{array}{l}\text { Implement } \\
\text { asi } \\
\text { (implement } \\
\text { ation) }\end{array}$ & $\begin{array}{l}\text { Melakukan uji } \\
\text { coba terbatas. } \\
\text { Uji coba terbatas } \\
\text { dilakukan } \\
\text { dengan } 2 \text { tahap } \\
\text { yaitu uji coba } \\
\text { kelompok kecil } \\
\text { dan uji coba } \\
\text { kelompok besar. }\end{array}$ & $\begin{array}{l}\text { Diperoleh data } \\
\text { tentang } \\
\text { kepraktisan dan } \\
\text { keefektifandari } \\
\text { media } \\
\text { pembelajaran. }\end{array}$ \\
\hline $\begin{array}{c}\text { Evaluasi } \\
\text { (evaluation } \\
\text { ) }\end{array}$ & $\begin{array}{l}\text { Melakukan } \\
\text { revisi terhadap } \\
\text { produk } \\
\text { berdasarkan } \\
\text { hasil uji coba } \\
\text { terbatas bila } \\
\text { diperlukan. }\end{array}$ & $\begin{array}{l}\text { Dihasilkannya } \\
\text { Prototype Final } \\
\text { yang sudah } \\
\text { direvisi sesuai } \\
\text { dengan hasil uji } \\
\text { coba terbatas } \\
\text { dan telah } \\
\text { memenuhi } \\
\text { kriteria } \\
\text { valid,praktis, } \\
\text { dan efektif. }\end{array}$ \\
\hline
\end{tabular}

(Dimodifikasi dari Lee \& Owens, 2004) Pada tahap uji coba, untuk mengukur kelayakan sebuah media pembelajaran diperlukan suatu instrumen. Instrumen dalam pengertian umum adalah sesuatu yang dapat digunakan untuk mempermudah seseorang dalam melaksanakan tugas atau mencapai tujuan secara lebih efektif dan efisien (Arikunto, 2012). Instrumen pengumpulan data yang digunakan dalam penelitian ini, yaitu: angket validasi ahli media, angket validasi ahli materi, angket respons siswa, dan angket respons guru. Khusus untuk mengetahui tingkat validitas media pembelajaran diperlukan angket/lembar validasi ahli media dan materi. 
Indikator penilaian pada angket validasi ahli materi dan angket validasi ahli media menggunakan lima skala, yaitu: sangat baik (skor 5), baik (skor 4), cukup (skor 3), kurang(skor 2), dan sangat kurang (skor 1).Validitas dari media pembelajaran yang dikembangkan dalam penelitian ini ditentukan berdasarkan hasil penilaian tiga orang ahli, satu orangahlimedia, satu orang ahlimateri, dan satu orang guru matematika kelas VIII sebagai praktisi yang memberikan penilaiannya melalui angket/lembar validasi. Teknik analisis data yang digunakan dalam penelitian ini adalah teknik analisis data kualitatif dan deskriptif kuantitatif. Teknik analisis data kualitatif digunakan untuk mengelola data hasil review ahli media dan ahli materi. Hasil data ini kemudian digunakan untuk merevisi produk yang dikembangkan.

Teknik analisis data deskriptif kuantitatif digunakan untukmengelola data hasil angket validasi. Hasil analisis data ini kemudian digunakan untuk mengetahui validitasmedia pembelajaran yang dikembangkan.Kevalidan media pembelajaran yang dikembangkan dapat diketahui melalui hasil penilaian para ahli dengan menggunakan lembar validasi/angket.

\section{HASIL DAN PEMBAHASAN}

Media pembelajaran Sistem Koordinat berbasis lectora inspire dengan pendekatan saintifik yang dikembangkan ini dirancang agar menjadi media pembelajaran yang dapat membantu siswa kelas VIII dalam mempelajari materi sistem koordinat, dan tentunya mampu mengakomodasi permasalahanpermasalahan dalam penerapan Kurikulum 2013 terutama berkaitan dengan keterbatasan sumber/perangkat pembelajaran. Pembelajaran akan menjadi lebih menarik dan lebih mengeksplor pengetahuan siswa untuk mengikuti pembelajaran dengan adanya media pembelajaran berbasis lectora inspire dengan pendekatan saintifik yang dikembangkan ini.

Pada tahap desain dari model ADDIE, dilakukan perancangan kerangka media pembelajaranyang akan dikembangkan. Langkah pertama dalam tahap ini adalah membuat flowchart dari media pembelajaran yang menggambarkan alur program dari awal hingga akhir berdasarkan hasil yang diperoleh pada tahap analisis. Dengan adanya flowchart akan mempermudah proses pengaturan navigasi dalam media pembelajaran. Setelah membuat flowchart, langkah selanjutnya adalah membuat rancang bangun dari media pembelajaran yang dikembangkan. Rancang bangun dibuat sebagai pedoman dalam proses pembuatan media pembelajaran menjadi sebuah program yang utuh.

Rancang bangun dalam penelitian ini disusun secara sederhana, jelas, dan memuat beberapa hal, antara lain: (1) kompetensi dasar dan indikator pembelajaran yang ingin dicapai dalam pembelajaran menggunakan media yang dikembangkan; (2) butir-butir materi yang dibelajarkan; (3) deskripsi kegiatan pada setiap halaman; (4) komponen-komponen yang termuat dalam setiap halaman; (5) desain tampilan (layout) setiap halaman, 6) flowchart.

Deskripsi kegiatan dalam rancang bangun memuat skenario kegiatan yang dilakukan siswa pada setiap halaman dan alur pembelajaran. Komponen, navigasi, dan desain tampilan dalam rancang bangun dicantumkan secara sederhana, jelas, dan konsisten untuk memudahkan pengimplementasian rancang bangun 
menjadi program media pembelajaran. Berikut adalah sekilas mengenai rancangan awal dari media pembelajaran sistem koordinat berbasis lectora inspire dengan pendekatan saintifik.

Setelah tahap desain dilaksanakan, implementasi rancang bangun media pembelajaran dilakukan pada tahap pengembangan. Pada tahap ini dilakukan tahap pengembangan produk awal media pembelajaran interaktif dengan menerapkan rancangan yang telah dibuat pada tahap desain model ADDIE. Tujuan dilakukannya tahap ini adalah menghasilkan Prototype I Media Pembelajaran Materi Sistem Koordinat yang memenuhi kriteria kualitas produk yang baik. Pada tahap ini dilakukan pengembangan media pembelajaran sistem koordinat menggunakan lectora inspire sebagai aplikasi pembuat layout dan kuis GeoGebra sebagai media eksplorasi, serta Adobe After Premiere Pro dan Camtasia Studio sebagai aplikasi pengeditan suara dan video.

Secara garis besar, di dalam media pembelajaran ini terdapat video permasalahan, materi pelajaran, media eksplorasi dan latihan soal untuk menguji pemahaman siswa terkait materi Sistem Koordinat. Berikut akan diuraikan secara singkat hal-hal yang termuat dalam Media Pembelajaran Sistem Koordinat Berbasis Lectora Inspire dengan Pendekatan Saintifik.

Untuk memulai pembelajaran siswa dapat menekan tombol "Start".Dalam halaman utama terdapat beberapa menu yaitu menu: (1) KI/KD; (2) Permasalahan; (3) Evaluasi; dan (4) Tentang Kami. Pada halaman utama juga terdapat tombol suara, exit, serta help yang berisi tentang kegunaan tombol navigasi media pembelajaran. Adapun tampilan awal dan halaman utama media seperti Gambar 1 berikut.

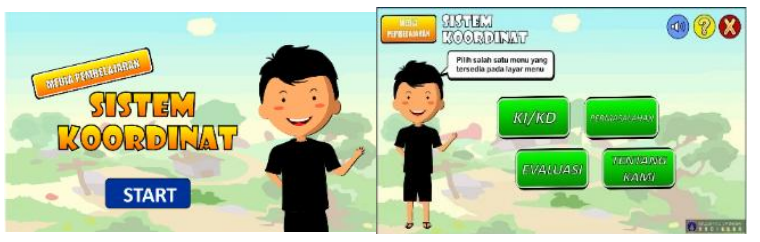

Gambar 1. Tampilan Awal dan Halaman Utama Media

Pada menu KI/KD terdapat dua halaman, halaman pertama yang berisikan kompetensi intidan kompetensi dasar, serta halaman kedua berisikan indikator pencapaian kompetensi dan tujuan pembelajaran mengenai tentang materi sistem koordinat. Pada halaman permasalahan, terdapat halaman awal yaitu halaman pemberitahuan dari halaman permasalahan utama oleh karakter "Jaya" untuk memilih permasalahan yang dianjurkan terlebih dahulu. Untuk menuju halaman permasalahan utama, siswa diminta untuk menekan tombol "Lanjutkan" pada halaman pemberitahuan permasalahan. Setelah menekan tombol "Lanjutkan", halaman permasalahan utama akan tampak dengan tiga permasalahan yaitu : (1) Permasalahan I; (2) Permasalahan II; dan (3) Permasalahan III. Halaman dari tiap permasalahan akan tampil apabila siswa menekan tombol dari permasalahan tersebut. Masing-masing permasalahan memiliki sub bab materi yang berbeda-beda. Tampilan halaman $\mathrm{KI} / \mathrm{KD}$ dan halaman menu permasalahan dapat dilihat pada Gambar 2 berikut.

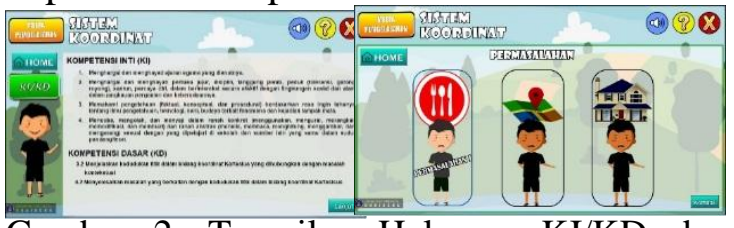
Gambar 2. Tampilan Halaman KI/KD dan Permasalahan Utama

Pada halaman permasalahan, dimasing-masing permasalahan memiliki komponen yang sama namun materi yang jelaskan berbeda-beda. Salah satunya halaman permasalahan I terdapat empat menu yaitu: (1) Video; (2) Materi; (3) Media Eksplorasi; dan (4) Latihan. Menu 
video pada halaman permasalahan, salah satunya video permsalahan I menampilkan video permasalahan mengenai kehidupan sehari-hari tentang sistem koordinat dengan subbab materi posisi titik terhadap sumbu-x dan sumbu-y. Jika masih belum mengetahui permasalahan yang dicantumkan, siswa dapat mengulang kembali video permasalahan. Tampilan dari halaman permasalahan I dan menu video dapat dilihat pada Gambar 3.

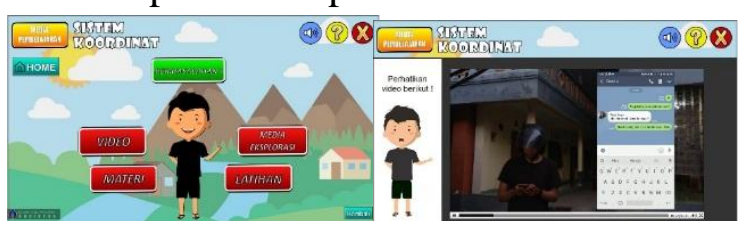

Gambar 3. Tampilan Halaman

Permasalahan I dan Vidio Permasalahan I

Menu materi salah satunya pada halaman permasalahan I menampilkan video materi tentang sistem koordinat dengan sub-bab materi posisi titik terhadap sumbu-x dan sumbu-y. Video ini bertujuan untuk mempelajari materi dasar dan teori posisi titik terhadap sumbu-x dan sumbuy. Jika masih belum paham, siswa dapat mengulang kembali video pembelajaran tersebut.Pada halaman permasalahan I terdapat menu media eksplorasi. Apabila siswa menekan menu media eksplorasi ini, maka akan muncul sebuah halaman baru yang menampilkan sebuah media GeoGebra. Dengan adanya media GeoGebra siswa dapat melihat visualisasi dari sistem koordinat khususnya materi mengenai posisi titik terhadap sumbu-X dan sumbu-y. Pada menu ini, siswa dapat berlatih dan membuktikan sesuatu agar menemukan sebuah konsep mengenai posisi titik terhadap sumbu-x dan sumbuy. Hal tersebut dapat dilakukan pada media GeoGebra yang tersedia, dan caranya adalah memindahkan titik A dengan bantuan tombol berwarna kuning dan setelah itu, mencatat data yang diperoleh pada LKS yang telah disediakan. Tampilan dari menu Materi Permasalahan I dan Media Eksplorasi dapat dilihat pada Gambar 4 berikut.

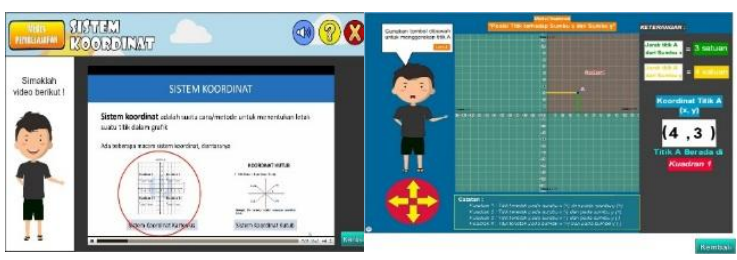

Gambar 4. Tampilan Menu Materi dan Media Eksplorasi Permasalahan I

Pada halaman permasalahan I selain menu media eksplorasi yang menggunakan GeoGebra, menu latihan pun juga menggunakan GeoGebra. Apabila siswa menekan menu latihan ini, maka akan muncul sebuah halaman baru yang menampilkan sebuah media GeoGebra. Namun, pada halaman ini siswa diminta menyelesaikan permasalahan yang ada berkaitan dengan video permasalahan I yang sudah diputar sebelumnya pada halaman permasalahan I.Siswa diminta untuk menginput jawaban pada kolom terkait dengan posisi suatu objek. Apabila siswa menjawab dengan benar maka akan muncul tanda rumput, namun apabila siswa salah menjawab maka akan muncul tanda silang. Pada halaman evaluasi terdapat beberapa soal terkait materi sistem koordinat yang bertujuan sebagai sarana latihan siswa dalam mengaplikasikan konsep sistem koordinat yang sudah dipelajari sebelumnya. Soal yang ditampilkan berupa soal pilihan ganda dengan empat opsi. Posisi dari tiap opsi soal akan berbeda setiap kali siswa membuka halaman evaluasi. Pada menu evaluasi, siswa diberikan waktu 10 menit untuk menjawab semua soal yang ada. Setelah siswa menyelesaikan semua soal maka akan muncul total skor yang ia peroleh.Untuk lebih jelasnya tampilan Menu Latihan dan 
Halaman Evaluasi dapat dilihat pada Gambar 5 berikut.

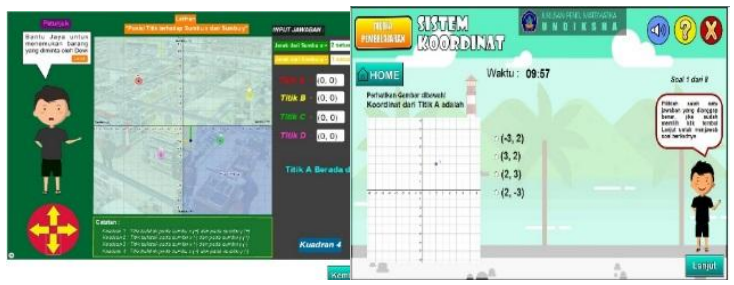

Gambar 5. Tampilan Menu Latihan dan

Evaluasi Permasalahan I

Setelah hasil dari rancang bangun media selesai diimplementasikan dan menghasilkan sebuah media pembelajaran, langkah selanjutnya dilakukannya uji kelayakan untuk mengukur kualitas dari media pembelajaran yang dikembangkan, khususnya tingkat validitasnya. Validitas diketahui melalui evaluasi media pembelajaran oleh ahli materi pembelajaran dan ahli media pembelajaran.

Validasi media pembelajaran dilakukan setelah peneliti menghasilkan media dalam bentuk Prototype I. Validasi dilakukan oleh ahli media dan ahli materi dengan cara memberikan penilaian dan saran terhadap media pembelajaran dengan mengisi angket/lembar validasi penilaian kelayakan. Rangkuman hasil penilaian terhadap media pembelajaran sistem koordinat berbasis lectora inspiredengan pendekatak saintifik dari masing-masing ahli dipaparkan pada Tabel 3 dan Tabel 4 berikut.

Tabel 4. Rangkuman Hasil Uji Validitas Media Pembelajaran oleh Ahli Materi

\begin{tabular}{cc}
\hline Skor Total Ahli Media & 36 \\
Rata-rata skor Total & 4,5 \\
\hline Kriteria & Sangat Valid \\
\hline
\end{tabular}

Tabel 3.Rangkuman Hasil Uji Validitas

Media Pembelajaran oleh Ahli Media

\begin{tabular}{cc}
\hline Skor Total Ahli I & 43 \\
Skor Total Ahli II & 45 \\
Rata-rata Skor Total & 4,4 \\
\hline Kriteria & Sangat Valid \\
\hline
\end{tabular}

Berdasarkan hasil penilaian dari ahli media dan ahli materi seperti pada Tabel 3 dan Tabel4 menunjukkan bahwa media pembelajaran yang dikembangkan termasuk ke dalam kriteria sangat baik dalam aspek validitas dan untuk selanjutnya siap untuk diujicobakan.

Berdasarkan tampilan media pembelajaran dan hasil validasi ahli di atas, dapat disimpulkan bahwa media pembelajaran yang dikembangkan diyakini dapat memfasilitasi peningkatan proses dan hasil belajar matematika siswa pada materi Sistem Koordinat. Hal ini berkenaan dengan taraf befikir siswa yang mana "dimulai dari berpikir kongkret menuju ke berpikir abstrak, dimulai dari berpikir sederhana menuju ke berpikir kompleks" (Sudjana, 2005: 3). Oleh karena itu, media pembelajaran yang dikembangkan ini diharapkan dapat membuat siswa lebih termotivasi untuk belajar karena hal-hal yang abstrak dapat dikongkretkan dan hal-hal yang kompleks dapat disederhanakan melalui pentahapan pada pendekatan saintifik. Penyajian di dalam media pembelajaran berbasis lectorainspire dengan pendekatan saintifik ini terdapat tahapan-tahapan pada pendekatan saintifik yang dilengkapi dengan video pembelajaran, materi, media eksplorasi, dan kuis. Komponenkomponen tersebut diharapkan mampu untuk memfasilitasi siswa untuk belajar secara aktif dan mandiri, serta memfasilitasi proses penemuan konsep matematika siswa (Wiraphati, 2018).

Hasil penelitian ini sejalan dengan hasil penelitian yang dilakukan oleh Ave Graceota (2016) yang menyatakan bahwa media pembelajaran pada materi sistem koordinat kelas VIII SMP yang berfokus pada media GeoGebra mampu sebagai 
media eksplorasi, serta alat bantu dalam menampilkan visualisasi dari materi sistem koordinat dengan baik dan efektif. Kelebihan dari media pembelajaran berbasis lectorainspire dengan pendekatan saintifik dibandingkan dengan hasil penelitian sebelumnya ini adalah dilengkapinya dengan video pembelajaran, materi, media eksplorasi, dan kuis sehingga media pembelajaran ini tidak hanya berkedudukan sebagai pelengkap pembelajaran saja. Selain itu, sejalan juga dengan hasil penelitian Wiraphati (2018) yang menyatakan bahwa media pembelajaran berbasis TIK dengan pendekatan 5M mampu efektif meningkatkan kemampuan pemahaman konsep matematika siswa pada materi Statistika. Hal itu menunjukkan bahwa hasil penelitian ini memberikan keyakinan bahwa penerapan media pembelajaran berbasis TIK dengan pendekatan saintifik dipandang mampu mendukung penerapan Kurikulum 2013 pada mata pelajaran matematika.

Berdasarakan paparan tersebut diatas, dapat disimpulkan bahwa produk berupa media pembelajaran yang dihasilkan dari penelitian ini tentu memiliki kelebihan dan kekurangan. Kelebihan dari Media Pembelajaran Sistem Koordinat Berbasis Lectora Inspire dengan Pendekatan Saintifik, yaitu : (1) media pembelajaran dapat membantu siswa untuk belajar mandiri ataupun membantu guru dalam proses pembelajaran di kelas; (2) fasilitas eksplorasi yang terdapat didalamnya, sehingga siswa dapat melakukan percobaan berkali-kali sehingga siswa menemukan konsep dari sistem koordinat; (3) disesuaikan dengan pendekatan yang diterapkan pada kurikulum 2013, agar media pembelajaran membantu siswa untuk menemukan konsep sesuai dengan pemahamanya sendiri. Sedangkan kekurangan dari media pembelajaran ini, yaitu tidak terdapat materi prasyarat pada media ini sehingga siswa wajib memahami materi prasyarat dari sistem koordinat agar lebih mudah dalam menggunakan media pembelajaran. Selain itu menggunakan media pembelajaran memerlukan waktu yang relatif lebih lama bagi siswa untuk memahami konsep sistem koordinat apabila dibandingkan dengan media konvensional dengan bantuan seorang guru, namun konsep yang ditemukan dapat digunakan dalam berbagai situasi.

\section{SIMPULAN DAN SARAN}

Berdasarkan hasil analisis data dan pembahasan yang telah diuraikan, dapat ditarik kesimpulan, yaitu: (1) media pembelajaran yang dikembangkan adalah media pembelajaran berbasis lectora inspire dengan pendekatan saintifik untuk siswa SMP yang dirancang agar dapat dimanfaatkan oleh siswa dalam mempelajari materi sistem koordinat pada Kurikulum 2013; (2) rancang bangun media pembelajaran sistem koordinat berbasis lectora inspire dengan pendekatan saintifik untuk siswa SMP disusun secara sederhana, jelas, dan terdiri dari kompetensi inti dan kompetensi dasar, butir-butir materi yang dibelajarkan, deskripsi kegiatan pada setiap halaman, komponen-komponen yang termuat dalam setiap halaman, desain tampilan (layout) setiap halaman, dan flowchart; (3) hasil implementasi rancang bangun berbentuk software media pembelajaran yang memuat video permasalahan, materi, media eksplorasi dan latihan soal untuk menguji pemahaman siswa terkait materi sistem koordinat; dan (4) Hasil validasi ahli menyatakan bahwa media 
pembelajaran yang dikembangkan tergolong pada kategori sangat valid dengan sedikit perbaikan, dan siap untuk diujicobakan terbatas pada tahap implementation.

\section{SARAN}

Disarankan kepada guru untuk memanfaatkan media pembelajaran yang dikembangkan sebagai penunjang pembelajaran berbasis TIK dan untuk mendukung penerapan Kurikulum 2013. Disamping itu, siswa disarankan untuk memanfaatkan media pembelajaran yang dikembangkan sebagai sarana dalam pembelajaran sehingga memberikan pengalaman belajar yang menyenangkan, efektif, dan praktis di mana dan kapan saja.

\section{DAFTAR PUSTAKA}

Adipurnomo, H. (2006). Sumber dan media pembelajaran. Malang: Departemen Pendidikan Nasional.

Arsyad, A. (2011). Media pembelajaran. Jakarta: PT Raja Grafindo Persada.

Arikunto, S. (2012). Dasar-dasar evaluasi pendidikan. 2 ed. Jakarta: PT Bumi Aksara.

Daryanto.

(2014).Pendekatan pembelajaran saintifik kurikulum 2013. Yogyakarta: Grava Media.

Graceota, Ave. (2016). Pengembangan media pembelajaran matematika materi sistem koordinat berbasis game flash untuk siswa kelas VIII SMP. Skripsi (Tidak diterbitkan). Program Studi Pendidikan Matematika Fakultas Keguruan Dan Ilmu Pendidikan, Universitas Kristen Satya Wacana.

Hamalik, Oemar. (2011). Kurikulum dan pembelajaran. 1 ed. Jakarta: Bumi Aksara.

Lee, William.W, dan Diana L. Owens. (2004). Multimedia-based instructional design. San Fransisco: Pfeiffer
Mas'ud, M. (2012). Membuat mulltimedia pembelajaran dengan lectora. Yogyakarta: Pustaka Shonif.

Musfiqon. (2012). Pengembangan media \& sumber pembelajaran. Jakarta: Prestasi Pustaka.

Nieveen, et. al. (1999). Principles and methods of development research. The Netherlands: University of Twente.

Paradesa, R. (2016). "Pengembangan bahan ajar geometri transformasi berbasis visual". Jurnal Pendidikan Matematika RAFA, Volume 02, Nomor 01, ISSN: $2460-8718$.

Parwati, Suryawan, \& Ratih. (2018). Belajar dan pembelajaran. Surabaya: RajaGrafindo.

Peraturan Menteri Pendidikan dan Kebudayaan Republik Indonesia no. 103 Tahun 2014 tentang Pembelajaran Pada Pendidikan Dasar dan Pendidikan Menengah, 2014. Jakarta: Kemendikbud.

Putra, I.G.L.A.K. (2014). "Pengembangan media video pembelajaran dengan model addie pada pembelajaran bahasa inggris di sdn 1 selat". Jurnal EDUTECH Undiksha,Volume 02, Nomor 01.

Sudjana, N. (2005). Media pengajaran. Bandung: Sinar Baru Algensindo.

Sufairoh. (2016). Pendekatan saintifik dan pembelajaran k-13. Jurnal Pendidikan Profesional, Volume 5, Nomor 3, hal: 116-125.

Supriyanto, A. (2016). "Kolaborasi konselor, guru, dan orang tua untuk mengembangkan kompetensi anak usia dini melalui bimbingan komperensif." Jurnal CARE (Children Advisory Research and Education) 4 (1): 1-8.

Yuberti. (2014). "Penelitian dan pengembangan yang belum diminati dan perspektifnya". Jurnal Ilmiah Pendidikan Fisika 'Al Biruni,Volume 03, Nomor 02, ISSN: $2303-1832$. 
Zakaria, Pery. (2015). "Pengembangan instructional video berbasis multimedia untuk materi sistem koordinat". Dalam Seminar Nasional Matematika dan Pendidikan Matematika (hlm. 8594). Gorontalo: Universitas Negeri Gorontalo.

ISBN: 978.602.361.002.0.

Wirapathi. (2018). The development of transformation geometry learning medium with scientific approach as effort to improve the understanding concept skill. Journal of Education Technology, volume: 2, nomor: 2, halaman 76-81. 